\title{
Long-term in situ monitoring of spawning behavior and fecundity in Calyptogena spp.
}

\author{
Katsunori Fujikura ${ }^{1, *}$, Kasumi Amaki ${ }^{2}$, James P. Barry ${ }^{3}$, Yoshihiro Fujiwara ${ }^{1}$, \\ Yasuo Furushima $^{1}$, Ryoichi Iwase ${ }^{4}$, Hiroyuki Yamamoto ${ }^{1}$, Tadashi Maruyama ${ }^{1}$ \\ ${ }^{1}$ Extremobiosphere Research Center, Japan Agency for Marine-Earth Science and Technology (JAMSTEC), \\ 2-15 Natsushima-cho, Yokosuka, Kanagawa 237-0061, Japan \\ ${ }^{2}$ College of Bioresource Sciences, Nihon University, 1866 Kameino, Fujisawa, Kanagawa 252-8510, Japan \\ ${ }^{3}$ Monterey Bay Aquarium Research Institute (MBARI), 7700 Sandholdt Road, Moss Landing, California 95039, USA \\ ${ }^{4}$ Japan Agency for Marine-Earth Science and Technology (JAMSTEC), 2-15 Natsushima-cho, Yokosuka, \\ Kanagawa 237-0061, Japan
}

\begin{abstract}
Our knowledge of the reproductive biology and ecology of most deep-sea animals is very limited due to the logistic difficulties of deep-sea investigations. In this study, spawning by males and females of the vesicomyid bivalve Calyptogena soyoae and $C$. okutanii complex were observed in situ over 1 yr using the long-term deep-sea observatory located at cold seeps in Sagami Bay, Japan. Egg- and sperm-spawning events by clam aggregations occurred roughly 90 and 213 times $\mathrm{m}^{-2}$ for $1 \mathrm{yr}$, respectively, and the local population of the C. soyoae and C. okutanii complex yielded $5.8 \times 10^{8}$ eggs $\mathrm{m}^{-2} \mathrm{yr}^{-1}$ into the water column over the seep location studied. Males displayed a 'sprinkle siphon' behavior, waving their siphons left and right to sprinkle sperm into the water. Female spawning by egg release into the water column was always preceded by male spawning and decreasing near-bottom current speeds. Two hypotheses are proposed for cues to stimulate egg release by C. soyoae/okutanii females. First, a 'double trigger' hypothesis requires the presence of sperm in the water column and decreasing current speed before eggs are released. Second, a 'single trigger' hypothesis requires that egg release is induced when compounds in or released with sperm exceed a threshold concentration. These results demonstrate the utility of long-term observatories for studies of deep-sea reproductive biology, particularly for species characterized by rare, episodic spawning events.
\end{abstract}

KEY WORDS: Calyptogena · Spawning · Long-term observatory · Induction · Synchronization · Fecundity $\cdot$ Cold seep $\cdot$ Sagami Bay

Resale or republication not permitted without written consent of the publisher

\section{INTRODUCTION}

Successful fertilization is a critical factor in the lifehistory of free-spawning aquatic animals (e.g. Giese \& Kanatani 1987, Pechenik 2005). Although the literature concerning deep-sea reproductive biology is limited, reproductive patterns for deep-sea animals range from seasonal to continuous spawners (Gage \& Tyler 1991, Sheltema 1994, Young 2003). For example, seasonal spawners typically have mature gametes during spring or fall, following the elevated seasonal flux of organic carbon derived from dense phytoplankton blooms in surface waters (Tyler 1988). Animals inhabiting deepsea vents and seeps have both seasonal and continuous reproductive patterns (Tyler \& Young 1999, Young 2003). The majority of vent and seep species investigated to date appears to undergo continuous (asynchronous) gametogenesis (Van Dover 2000). Reports of reproduction in chemosynthetic bivalves include both seasonal and continuous spawning. Two mytilid species, Bathymodiolus azoricus (Colaço et al. 2006) and B. childressi (Tyler et al. 2006), have exhibited seasonal reproductive patterns. Vesicomyid bivalves are a common taxon at deep-sea vents and seeps, and have 
been reported to spawn continuously and seasonally. Histological and population structure analyses indicate that 4 vesicomyid species, Calyptogena magnifica (Berg 1985), C. soyoae (Endow \& Ohta 1990), C. laubiei and C. phaseoliformis (Fiala-Médioni \& Le Pennec 1989) have continuous reproductive patterns. C. kilmeri in Monterey Bay has been reported as a seasonal spawner (Lisin et al. 1997), but the sample size in that study was limited.

The deep-sea observatory was deployed as a multipurpose deep-sea platform for observations and measurements of biology, geophysics and oceanography in Sagami Bay seep environments, Japan. The observatory, deployed at the Off Hatsushima site in Sagami Bay, has a TV camera, a CTD and a current meter (Momma et al. $1994,1995,1998)$. In the present study we used continuous in situ observations of a cold seep in Sagami Bay to investigate the behavior and periodicity of spawning by vesicomyid clams. The chemosynthetic community under study is dominated by Calyptogena spp. bivalves and a Provanna sp. gastropod (Okutani \& Egawa 1985, Hashimoto et al. 1989, Fujikura et al. 2002). Continuous observations from this observatory strongly suggested that C. soyoae spawned continuously throughout the year (Momma et al. 1995, Fujiwara et al. 1998). In addition, Momma et al. (1995) hypothesized that male spawning was triggered by a rise in water temperature of approximately $0.2^{\circ} \mathrm{C}$. Using in situ manipulative experiments, Fujiwara et al. (1998) showed that sperm release by C. soyoae was indeed induced by a rise in water temperature, and that egg release followed male spawning by approximately $10 \mathrm{~min}$. The existence of synchronous reproduction in vent and seep taxa begs the question of how this synchrony is established and maintained. However, information on spawning behavior, frequency and spawning cues remains limited. Here, we report observations of the reproductive behavior of vesicomyid bivalves, in association with measurements of current speed and water temperature collected at the long-term deep-sea observatory over a period of $1 \mathrm{yr}$.

\section{MATERIALS AND METHODS}

Long-term deep-sea observatory. The long-term deep-sea observatory system was deployed at the Off Hatsushima cold seep site in Sagami Bay $\left(35^{\circ} 00.1^{\prime} \mathrm{N}, 139^{\circ} 13.5^{\prime} \mathrm{E}, 1174 \mathrm{~m}\right.$ deep) during September 1993 (Fig. 1) (Momma et al. 1994). The observatory is composed of 3 main components: the un- dersea cable and observatory platform, a shore station on Hatsushima Island, and a shore station at JAMSTEC (Yokosuka City). Detailed specifications of the system are provided by Momma et al. (1994, 1995, 1998). In situ video imagery of a vesicomyid bivalve assemblage at the Hatsushima seep environment was recorded between 17 February 1994 and 16 February 1995 using a Panasonic video camera (Model CAM-92, 3 CCD). The camera could be controlled (zoom, focus, pan and tilt) from the shore station on Hatsushima Island. Approximately once per week, continuous video was recorded for 10 to $20 \mathrm{~h}$. In total, $1356 \mathrm{~h}$ of video was recorded (Table 1). Water temperature and current speed were measured at $1 \mathrm{~Hz}$ using a CTD (Sea Bird SBE-9plus) and an electromagnetic current meter (ALEC Electronics), respectively.

Table 1. Hours of video recorded during each month between February 1994 and February 1995

\begin{tabular}{|llr|}
\hline Year & Month & Recording time (h) \\
\hline $\mathbf{1 9 9 4}$ & Feb & 74 \\
& Mar & 122 \\
& Apr & 150 \\
& May & 72 \\
& Jun & 118 \\
& Jul & 100 \\
& Aug & 100 \\
& Sep & 102 \\
& Oct & 114 \\
& Nov & 100 \\
$\mathbf{1 9 9 5}$ & Dec & 142 \\
& Jan & 104 \\
& Feb & 58 \\
& Total & 1356 \\
\hline
\end{tabular}

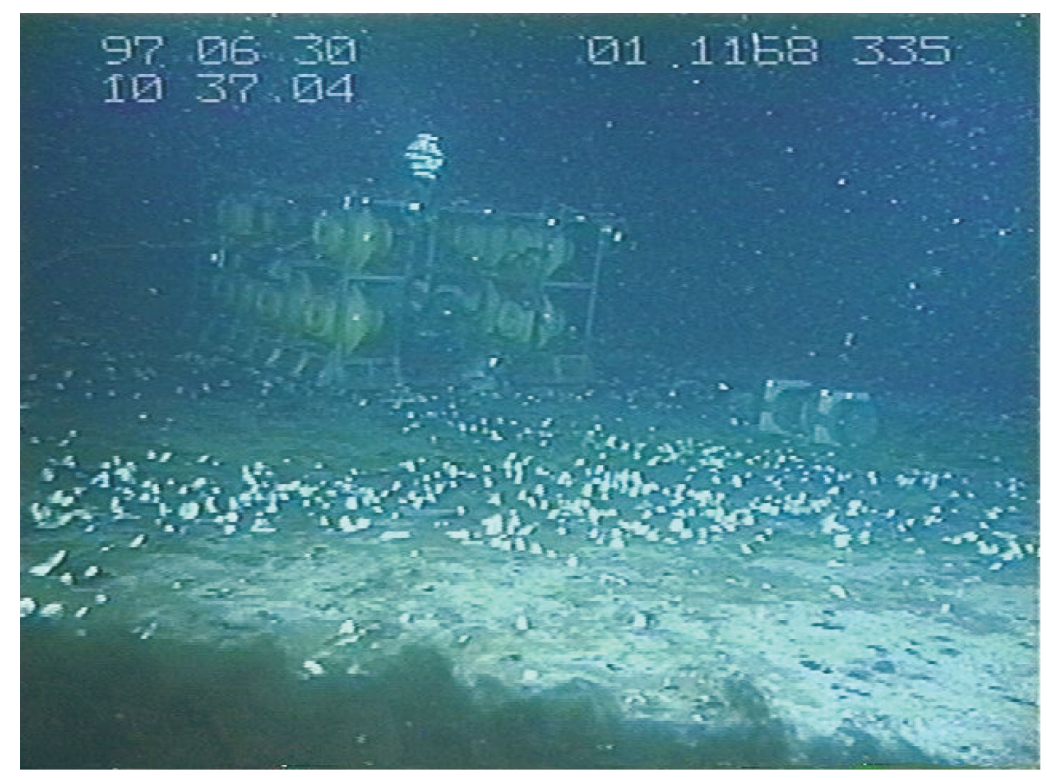

Fig. 1. Deep-sea observatory near aggregations of vesicomyid bivalves at the Off

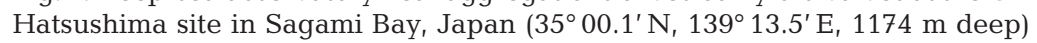


Estimation of spawning frequency. Spawning by male and female vesicomyids was detectable in video records by the release of gametes into the water column (Fujiwara et al. 1998). Male spawning was observed as the release of milky fluids (sperm) from siphons. Female spawning appeared as the ejection of numerous minute particles (eggs) from siphons. Male and female spawning was considered to be synchronous if egg release by females occurred within $60 \mathrm{~min}$ of the initiation of male spawning.

The estimated monthly frequencies of sperm release $\left(S_{\mathrm{m}}\right)$ and egg release $\left(E_{\mathrm{m}}\right)$ events in the observation area during each month were calculated by the following expressions:

$$
\begin{aligned}
S_{\mathrm{m}} & =N_{\mathrm{sm}} \times H_{\mathrm{m}} / T_{\mathrm{m}} \\
E_{\mathrm{m}} & =N_{\mathrm{em}} \times H_{\mathrm{m}} / T_{\mathrm{m}}
\end{aligned}
$$

where $N_{\mathrm{sm}}$ is the number of sperm release events during the period of video recorded in each month and $N_{\mathrm{em}}$ is the number of egg release events during the period of video recorded in each month. $H_{\mathrm{m}}$ is total hours per month (e.g. for January, $H_{\mathrm{m}}=24[\mathrm{~h}] \times 31[\mathrm{~d}]=744$ ). $T_{\mathrm{m}}$ is the total hours of video recorded during each month. Additionally, the estimated annual frequencies of sperm release $\left(S_{\mathrm{a}}\right)$ and egg release $\left(E_{\mathrm{a}}\right)$ events in the observation area were estimated as follows:

$$
\begin{aligned}
& S_{\mathrm{a}}=N_{\mathrm{sy}} \times A_{\mathrm{h}} / V_{\mathrm{h}} \\
& E_{\mathrm{a}}=N_{\mathrm{ey}} \times A_{\mathrm{h}} / V_{\mathrm{h}}
\end{aligned}
$$

where $N_{\text {sy }}$ is the number of sperm release events observed during the total video recording time for $1 \mathrm{yr}$ and $N_{\text {ey }}$ is the number of egg release events observed during the total video recording time for $1 \mathrm{yr} . A_{\mathrm{h}}$ is the total hours per year $(8760=24 \mathrm{~h} \times 365 \mathrm{~d})$, and $V_{\mathrm{h}}$ is the total hours of video recorded for $1 \mathrm{yr}(1356 \mathrm{~h})$.

Identification of vesicomyid bivalves. Two species of vesicomyid bivalves, Calyptogena soyoae and C. okutanii, inhabit the Off Hatsushima seep site (Kojima \& Ohta 1997). It was not possible to discriminate between these species using video imagery from the benthic observatory. Thus, we use the nomenclature C. soyoae/ okutanii to describe this Calyptogena spp. complex in this study. By detailed morphological analysis, C. okutanii represented $74.4 \%$ of this complex (Ito 2004). Incidentally, Momma et al. (1995) and Fujiwara et al. (1998) treated this species complex as C. soyoae.

\section{RESULTS}

\section{Sperm release events}

Thirty-three complete sperm release events were observed in video recorded by the long-term deep-sea observatory during 1 yr (Table 2). Sperm release typi- cally was observed as the continuous release of milky fluids from the exhalent siphon for 10 to $20 \mathrm{~s}$. These milky fluids appeared to be neutrally buoyant, neither sinking to the seabed nor rising rapidly, and they drifted down-current. Of approximately 40 males observed, 5 exhibited a 'sprinkle siphon' behavior during which males waved their siphons left and right to sprinkle or disperse sperm into the water (Fig. 2). The water column immediately above Calyptogena soyoae/okutanii aggregations became a cloudy white color due to the simultaneous spawning of many males during each sperm release event (Fig. 3). Such 'cloudy' conditions persisted for 3 to 80 min over all events observed. Because water clarity decreased during each event, it was not possible to determine if individual clams spawned repeatedly. Non-vesicomyid species exhibited no obvious change in behavior or distribution in response to clam spawning events. During and after spawning, predators did not gather in or around vesicomyid aggregations.

\section{Egg release events}

Female spawning events were observed 14 times during the 1 yr observation period (Table 2). All egg release events were synchronized with sperm release. Females typically released eggs through the exhalant siphon, but occasionally eggs were also ejected from the inhalant siphon. Eggs were propelled upward during release, and spawning was generally continuous for nearly $10 \mathrm{~s}$. A few specimens released eggs intermittently for $90 \mathrm{~s}$. In each case, egg release followed sperm release by 7 to $50 \mathrm{~min}$ of the first male spawning, and usually within ca. 10 min (Table 2).

\section{Spawning frequency}

Sperm release events were observed in all months except February 1995. Egg release was not observed in February, July or September. The estimated monthly frequencies for sperm $\left(S_{\mathrm{m}}\right)$ and egg $\left(E_{\mathrm{m}}\right)$ release ranged from 0 to 33 and 0 to 22 events $\mathrm{mo}^{-1}$, respectively, with no apparently seasonal pattern (Fig. 4). The estimated annual sperm $\left(S_{\mathrm{a}}\right)$ release frequency was 213 events $\mathrm{yr}^{-1}$, compared with 90 annual egg release events. The size of the observation area visible using the long-term deep-sea observatory was approximately $1 \mathrm{~m}^{2}$ (Momma et al. 1995). Therefore, sperm and egg release events in $1 \mathrm{~m}^{2}$ for $1 \mathrm{yr}$ are presumed to be approximately 213 and 90 times $\mathrm{yr}^{-1}$, respectively. In other words, sperm and egg release events occur roughly 4.1 and 1.7 times $\mathrm{wk}^{-1}$, respectively. 
Table 2. Calyptogena soyoae/okutanii. Start time of initial sperm and egg release. In situ observations using the long-term deepsea observatory at the Off Hatsushima site, Sagami Bay, Japan, from 17 February 1994 to 16 February 1995. Lunar phase represents the lunar day at noon in Japan (e.g. 0.0 d represents new noon). +++: large range of tide; ++: middle range of tide; +: small range of tide. Time is Japanese local time (GMT $+9 \mathrm{~h})$

\begin{tabular}{|c|c|c|c|c|c|c|c|c|c|}
\hline \multirow{3}{*}{$\begin{array}{l}\text { Year } \\
\mathbf{1 9 9 4}\end{array}$} & \multirow{3}{*}{$\begin{array}{c}\text { Date } \\
17 \text { Feb }\end{array}$} & \multicolumn{2}{|c|}{ - Start time (hh:mm) } & \multirow{3}{*}{$\begin{array}{c}\begin{array}{c}\text { Lunar } \\
\text { phase }\end{array} \\
6.5\end{array}$} & \multirow{3}{*}{$\begin{array}{c}\begin{array}{c}\text { Range } \\
\text { of tide }\end{array} \\
++\end{array}$} & \multicolumn{4}{|c|}{-Approx. time (hh:mm) } \\
\hline & & \multirow{2}{*}{$\begin{array}{c}\text { Sperm release } \\
09: 11\end{array}$} & \multirow{2}{*}{$\frac{\text { Egg release }}{\text { Absent }}$} & & & \multicolumn{2}{|c|}{ Lowest tide } & \multicolumn{2}{|c|}{ Highest tide } \\
\hline & & & & & & 02:00 & $15: 00$ & 08:00 & $21: 00$ \\
\hline & $17 \mathrm{Feb}$ & $21: 28$ & Absent & & & & & & \\
\hline & $11 \mathrm{Mar}$ & $10: 34$ & $10: 45$ & 28.5 & ++ & $10: 00$ & $23: 00$ & 05:00 & 16:00 \\
\hline & 11 Mar & $15: 57$ & $16: 05$ & & & & & & \\
\hline & 30 Mar & $12: 55$ & Absent & 17.8 & ++ & 00:00 & $13: 00$ & 06:00 & $19: 00$ \\
\hline & 16 Apr & $13: 22$ & $13: 31$ & 5.1 & ++ & 01:00 & $14: 00$ & 07:00 & $20: 00$ \\
\hline & $28 \mathrm{Apr}$ & $10: 56$ & Absent & 17.1 & ++ & $12: 00$ & & 05:00 & 19:00 \\
\hline & 26 May & $20: 42$ & $20: 51$ & 15.4 & +++ & $11: 00$ & & 04:00 & 19:00 \\
\hline & 27 May & 09:05 & Absent & 16.4 & +++ & 00:00 & $12: 00$ & 05:00 & $19: 00$ \\
\hline & 30 Jun & $06: 46$ & $06: 55$ & 20.8 & ++ & 03:00 & $15: 00$ & 09:00 & $22: 00$ \\
\hline & $8 \mathrm{Jul}$ & 09:43 & Absent & 28.8 & ++ & $10: 00$ & $23: 00$ & 03:00 & $17: 00$ \\
\hline & $21 \mathrm{Jul}$ & $12: 18$ & Absent & 12.2 & ++ & $10: 00$ & $22: 00$ & 02:00 & $17: 00$ \\
\hline & $22 \mathrm{Jul}$ & $15: 26$ & Absent & 13.2 & ++ & $10: 00$ & $23: 00$ & 03:00 & $17: 00$ \\
\hline & $28 \mathrm{Jul}$ & $19: 07$ & Absent & 19.2 & ++ & 02:00 & $14: 00$ & 08:00 & $20: 00$ \\
\hline & 11 Aug & $15: 55$ & 16:01 & 3.8 & ++ & 01:00 & $13: 00$ & 07:00 & $19: 00$ \\
\hline & 12 Aug & $02: 57$ & 03:06 & 4.8 & ++ & 02:00 & $14: 00$ & 08:00 & $20: 00$ \\
\hline & 19 Aug & $12: 18$ & $12: 25$ & 11.8 & ++ & 09:00 & $22: 00$ & 02:00 & $16: 00$ \\
\hline & $2 \mathrm{Sep}$ & $07: 50$ & Absent & 25.8 & ++ & 08:00 & $21: 00$ & 01:00 & $15: 00$ \\
\hline & $8 \mathrm{Sep}$ & $17: 18$ & Absent & 2.4 & ++ & $00: 00$ & $12: 00$ & 06:00 & $18: 00$ \\
\hline & 5 Oct & $10: 48$ & Absent & 29.4 & +++ & $11: 00$ & $23: 00$ & 05:00 & $16: 00$ \\
\hline & 5 Oct & $13: 13$ & Absent & & & & & & \\
\hline & 12 Oct & $10: 06$ & Absent & 7.0 & + & 04:00 & $17: 00$ & $12: 00$ & $21: 00$ \\
\hline & 20 Oct & $12: 43$ & 13:05 & 15.0 & +++ & $11: 00$ & $23: 00$ & 05:00 & $17: 00$ \\
\hline & 27 Oct & $17: 50$ & Absent & 22.0 & ++ & 03:00 & $15: 00$ & $10: 00$ & $20: 00$ \\
\hline & $25 \mathrm{Nov}$ & $13: 42$ & 14:02 & 21.6 & ++ & 02:00 & $15: 00$ & 09:00 & $20: 00$ \\
\hline & $25 \mathrm{Nov}$ & $16: 00$ & Absent & & & & & & \\
\hline & $9 \mathrm{Dec}$ & $16: 02$ & Absent & 6.1 & ++ & 02:00 & $16: 00$ & $10: 00$ & $20: 00$ \\
\hline & $27 \mathrm{Dec}$ & $17: 31$ & $18: 21$ & 24.1 & + & 05:00 & $19: 00$ & 00:00 & $11: 00$ \\
\hline & $28 \mathrm{Dec}$ & 07:03 & $07: 12$ & 25.1 & ++ & 06:00 & $20: 00$ & 01:00 & $12: 00$ \\
\hline \multirow[t]{4}{*}{1995} & 19 Jan & $20: 55$ & Absent & 17.7 & ++ & 00:00 & $12: 00$ & 07:00 & $18: 00$ \\
\hline & 19 Jan & $23: 24$ & Absent & & & & & & \\
\hline & $20 \mathrm{Jan}$ & 06:05 & $06: 35$ & 18.7 & ++ & 00:00 & $13: 00$ & 07:00 & $18: 00$ \\
\hline & $26 \mathrm{Jan}$ & 09:05 & $09: 47$ & 24.7 & + & 05:00 & $19: 00$ & 01:00 & 11:00 \\
\hline
\end{tabular}

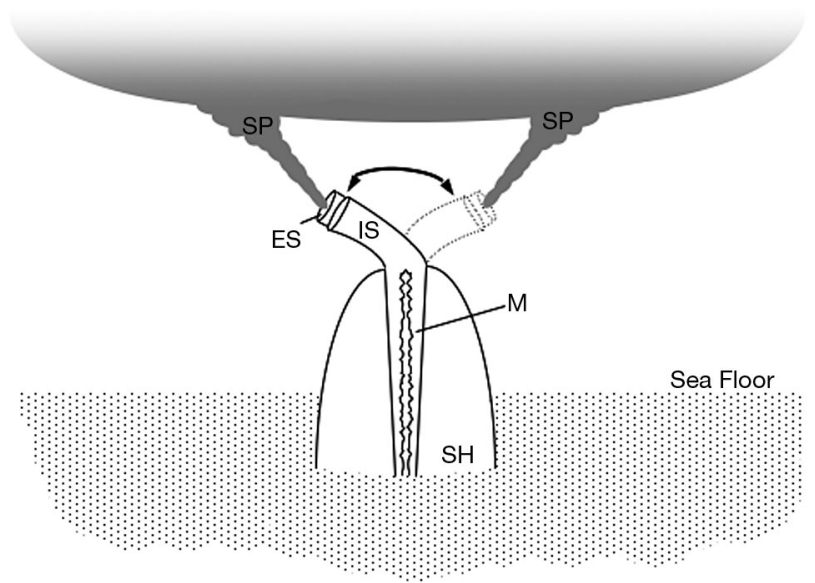

Fig. 2. Calyptogena soyoae/okutanii. 'Sprinkle siphon' sperm release behavior during which sperm are released from the exhalant siphon. Males waved siphons left and right and sprinkled sperm into the water. ES: exhalant siphon; IS: inhalant siphon; M: mantle; SH: shell; SP: sperm

\section{Induction of spawning}

Egg release was always synchronized with sperm release events, but did not occur during all male spawning events. Inspection of current speed and water temperature during and preceding spawning events indicates that a change in current speed or water temperature or both was associated with spawning. Current speed and water temperature were not recorded in 5 of 33 sperm release events and 2 of 14 egg release events due to temporary failures of these sensors. For all 12 egg release events for which flow and temperature data are available, egg release occurred following a decrease in current velocity of from 50 to $200 \mathrm{~mm} \mathrm{~s}^{-1}$ in the 30 to $120 \mathrm{~min}$ before spawning (Fig. 5). Typically, egg release commenced as current speed increased following a recent minimum value. In some cases, egg release began as current speed increased following an extended period of low current speed (for example, a 

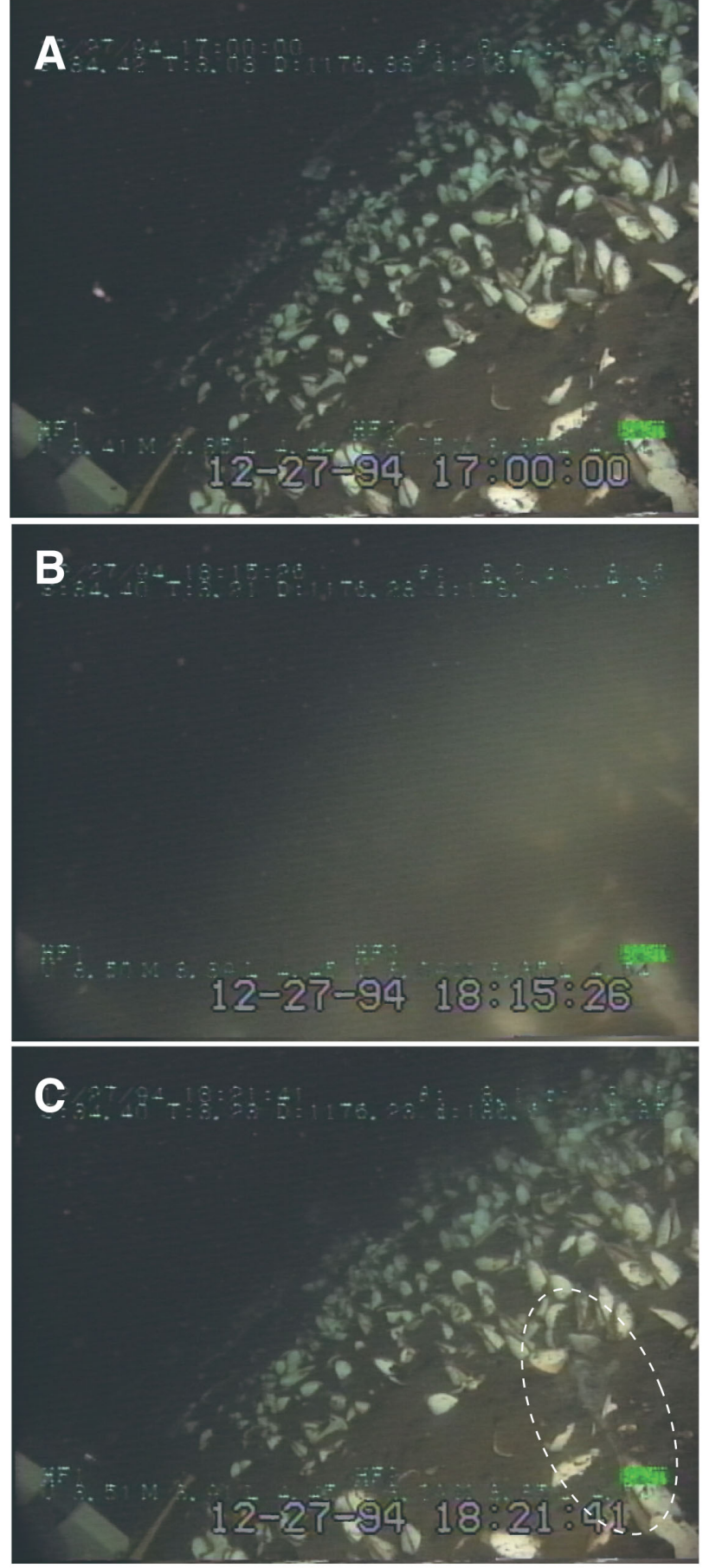

Fig. 3. Calyptogena soyoae/okutanii. Video images of in situ spawning. (A) Before spawning event. (B) Sperm release event. Seawater is cloudy due to high sperm concentrations. (C) Egg release (lower right specimen, encircled). Egg release appears as rising smoke. Time is Japanese local time $(\mathrm{GMT}+9 \mathrm{~h})$

pattern on 11 August 1994 in Fig. 5). In 10 of 14 cases, egg release events occurred within $2 \mathrm{~h}$ of the lowest or highest tide (Table 2). Also, the release events were observed in various lunar phases (Table 2). In 13 out of 33

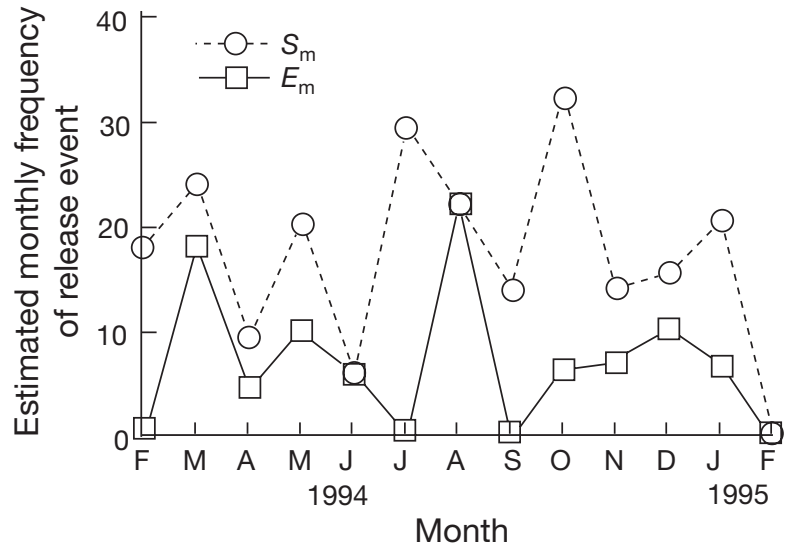

Fig. 4. Calyptogena soyoae/okutanii. Estimated monthly frequencies of sperm release $\left(S_{\mathrm{m}}\right)$ and egg release $\left(E_{\mathrm{m}}\right)$ events during each month at cold seep areas in Sagami Bay

cases, sperm release was preceded by an increase in water temperature without a clear change in current speed. In these cases, egg release did not follow sperm release (e.g. 28 July 1994; Fig. 6A). For 3 sperm release events during which current speed also decreased, female spawning was not observed (e.g. 27 October 1994; Fig. 6B). Egg release was only observed following spawning by males, including periods with decreasing current speed, but no male spawning (Fig. 6C).

\section{DISCUSSION}

Momma et al. (1995) and Fujiwara et al. (1998) suggested that reproduction in Calyptogena soyoae is continuous (i.e. no seasonality). Our results also strongly support a non-seasonal pattern of reproduction. In contrast, Lisin et al. (1997) suggested that C. kilmeri from cold seeps in Monterey Bay spawn seasonally during late fall and spring, based on gonadal development. These differences in reproductive periodicity are puzzling, considering the very close phylogenetic relationship between C. kilmeri and the C. soyoae/okutanii complex. In fact, $C$. kilmeri may be conspecific with $C$. soyoae based on molecular analyses presented by Kojima et al. (2004). Reproductive periodicity appears variable in chemosynthetic mussels. In contrast with the seasonal reproduction reported for Bathymodiolus azoricus and B. childressi (Colaço et al. 2006, Tyler et al. 2006), B. thermophilus is reported to be aseasonal (Van Dover 2000). Lisin et al. (1997) speculated that although $C$. kilmeri receives all or most of its nutrition from endosymbiotic bacteria, rich seasonal phytoplankton productivity off central California may contribute indirectly to the apparent seasonal repro- 

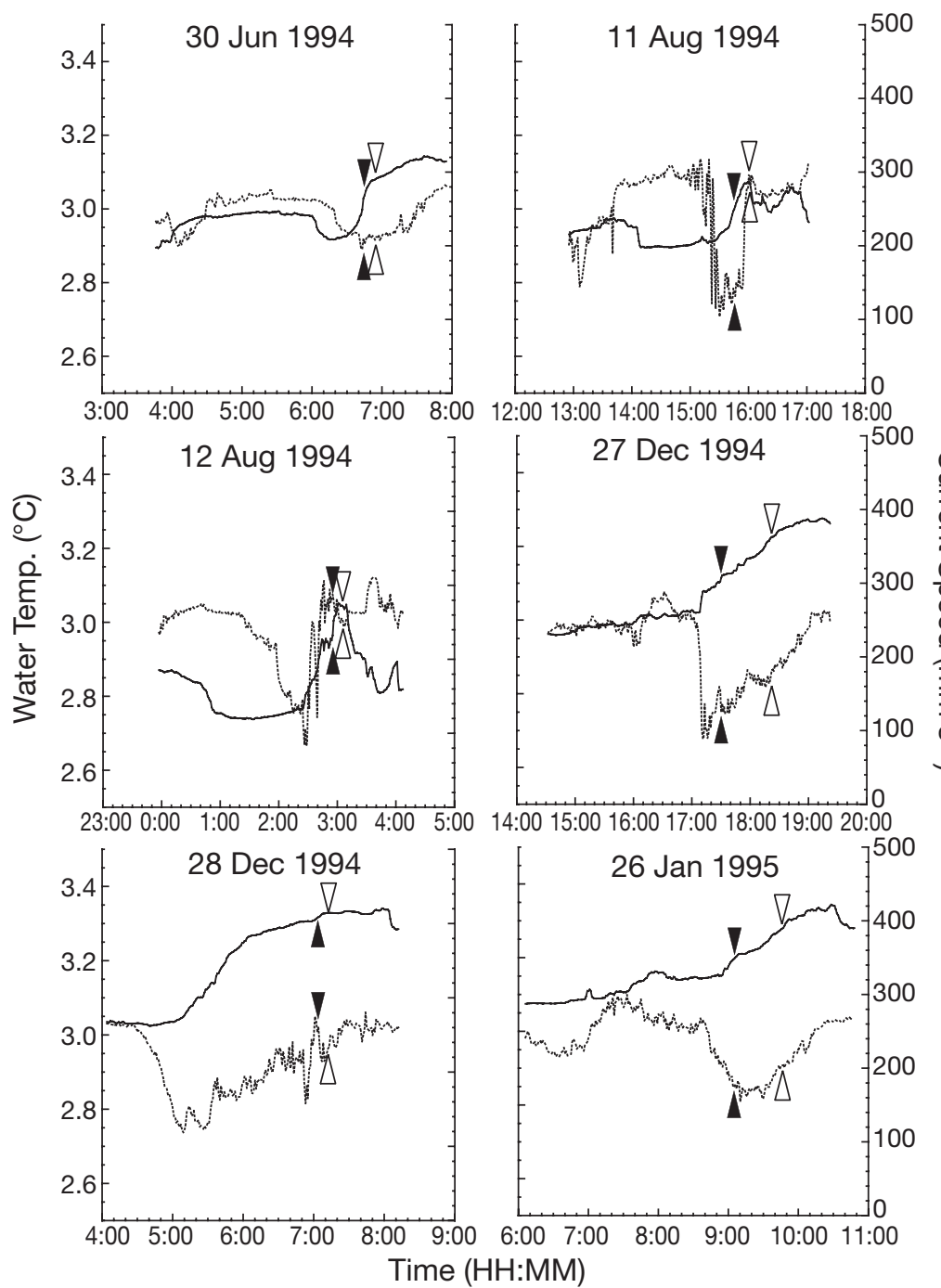

Fig. 5. Calyptogena soyoae/okutanii. Occurrence of sperm or egg release events corresponds to changes in current speed and water temperature from 3 $\mathrm{h}$ before sperm release to $1 \mathrm{~h}$ after sperm or egg release. Six out of 14 egg release events that were synchronized with sperm release are shown. $\boldsymbol{\Lambda}$ : start of sperm release; $\Delta$ : start of egg release; dashed line: current speed; solid line: water temperature. Time is Japanese local time (GMT $+9 \mathrm{~h})$

duction in C. kilmeri, by its possible influence on larval development and survival in the plankton. In addition, these authors indicate that their sample size is small, and additional study is required to determine the true nature of spawning periodicity, if any, in C. kilmeri. It is interesting to speculate on why C. soyoae/okutanii does not exhibit seasonal reproductive periodicity. One possibility is that C. soyoae/okutanii may rely wholly on endosymbiotic chemoautotrophic bacteria for nutrition (i.e. no filter feeding) (Sakai et al. 1987, Endow \& Ohta 1990). Bathymodiolus sp. mussels rely on bacterial symbionts and filter feeding for nutrition. Reproductive seasonality of $B$. childressi appeared to be correlated with peak production in oceanic surface waters and plankton production associated downward flux that may provide supplementary nutrition for adults (Tyler et al. 2006). In contrast, $C$. soyoae/okutanii, which rely wholly on symbiont production that is not linked nutritionally to surface production, are probably unaffected by variation in the sinking flux of organic carbon.

Observations using the deep-sea observatory indicate that the frequencies of sperm and egg release events for Calyptogena soyoae/okutanii are approximately 213 and 90 events $\mathrm{m}^{-2} \mathrm{yr}^{-1}$, respectively. Although few data are available concerning the number of sperm and eggs released per event, the large difference in spawning frequencies by males and females is very likely related to the different energy investment required for sperm and egg production. A single female $C$. kilmeri released approximately 3000 eggs during a single spawning event induced by serotonin injection (J. P. Barry unpubl. data). We estimated the fecundity of C. soyoae/okutanii using 2 assumptions. First, C. soyoae/okutanii releases the same number of eggs during each spawning event as observed for C. kilmeri, and, second, 1 individual C. soyoae/okutanii $\mathrm{m}^{-2}$ spawns during each event. The number of eggs spawned by the C. soyoae/okutanii population over $1 \mathrm{yr}$ is estimated as 3000 eggs female f $^{-1} \times$ 90 events $\mathrm{m}^{-2} \mathrm{yr}^{-1}$ equals $2.7 \times 10^{5}$ eggs $\mathrm{m}^{-2} \mathrm{yr}^{-1}$. Additionally, the area of cold seep communities at the Off Hatsushima site was estimated to be $2146.5 \mathrm{~m}^{2}$ (Fujikura et al. 2002). Thus, the population of C. soyoae/okutanii released $5.8 \times$ $10^{8}$ eggs $\mathrm{yr}^{-1}$ into the water column over the seep community at the Off Hatsushima site. C. okutanii occupied $74.4 \%$ of this population (Ito 2004). Based on this ratio, the number of released eggs of $C$. okutanii was $4.3 \times 10^{8}$ and that of C. soyoae was $1.5 \times 10^{8}$. Tyler \& Young (1999) commented that the fecundity of all vesicomyid species examined appears high, but has not been quantified. We believe that these are the first estimates of fecundity for vent and seep animals.

Spawning males of Calyptogena soyoae/okutanii were frequently observed waving their siphons left and right to sprinkle sperm into the water, termed 'sprinkle siphon' behavior (Fig. 2). Usually, several males released sperm simultaneously. Pennington 


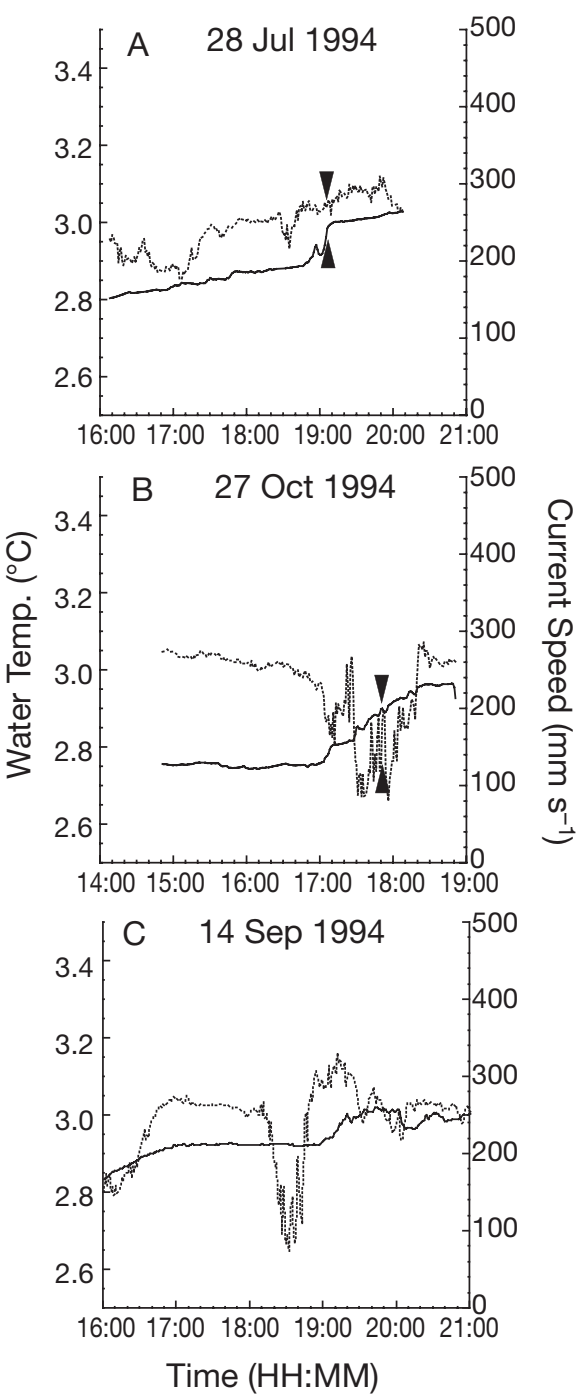

Fig. 6. Calyptogena soyoae/okutanii. No synchronization between sperm and egg release during changes of current speed and water temperature. (A) Sperm release occurred as water temperature increased. Current speed did not decrease, and no egg release was observed. (B) Sperm release was initiated after an increase in water temperature, but, in spite of a reduction in current speed, egg release was not observed. (C) No sperm or egg release was observed, despite a decrease in current speed. Time is Japanese local time $(\mathrm{GMT}+9 \mathrm{~h}) \cdot \boldsymbol{\Lambda}$ : start of sperm release

(1985) measured an increase in percent fertilization of echinoid eggs when several males were induced to spawn simultaneously. Presumably, synchronous spawning by $>1$ specimen of C. soyoae/okutanii is also likely to increase fertilization success. Eggs were rarely spawned from the inhalant siphon of females. In most bivalves, fertilization occurs in the surrounding water; sperm and eggs are shed into the suprabranchial cavity, then swept out the exhalant siphon with the exhalent current (Barnes 1969). Although eggs were released principally from the exhalant siphon, they were often also released in smaller numbers through the inhalant siphon. Future investigations are needed to determine the role of eggs spawned from the inhalant siphon.

All female spawning events of Calyptogena soyoae/ okutanii were synchronized with male spawning and occurred during a period of decreasing near-bottom current speeds. Decreasing near-bottom current speeds occur periodically due to variation in tidally driven currents, with periods of low current speed usually coinciding with the lowest and highest tides of each day (Momma et al. 1995). There was no relationship between egg release events and lunar phase. One of the primary benefits of reproductive synchronization for sperm and egg release by broadcast spawners is the increased likelihood of fertilization (Van Dover 2000). Higher percentages of echinoid eggs were fertilized when current velocities were low $\left(<0.2 \mathrm{~m} \mathrm{~s}^{-1}\right)$; swifter currents quickly diluted sperm and reduced rates of fertilization (Pennington 1985). Like the echinoids studied by Pennington (1985), fertilization success during broadcast spawning by seep vesicomyids is also expected to be highest during periods of low flow speeds. Because C. soyoae/okutanii is restricted to chemosynthetic communities, where they live in dense aggregations, long-distance dispersal may be unnecessary for its embryos and larvae. However, the length of the larval period, dispersal between seep habitats, lecithotrophy or planktotrophy, settlement cues, and most other aspects of the larval ecology of vesicomyids remain unknown.

The initiation of sperm release by Calyptogena soyoae followed an increase in water temperature of $>0.1^{\circ} \mathrm{C}$ in the preceding hours (Fujiwara et al. 1998). Our results also support the initiation by increased temperature (Fig. 5). Temperature anomalies $10^{\circ} \mathrm{C}$ higher than the normal ambient waters were reported from this site (Naka et al. 1991), apparently due to seep fluid derived from several sources including landderived groundwater, seawater and pore fluids (Tsunogai et al. 1996). Such large anomalies are probably caused by tectonic activities. The far milder temperature anomalies observed in this study $\left(\mathrm{ca} .<0.5^{\circ} \mathrm{C}\right)$ may be caused by variation in seep-related thermal fluxes.

Two hypotheses may explain the induction of egg release by Calyptogena soyoae/okutanii females. The first is the 'double trigger' hypothesis, in which egg release is induced by both the presence of sperm and decreasing current speed. The double trigger includes an increase in water temperature, which induces males to spawn, and a decrease in current speed. Females detect the presence of sperm in the water column and sense the low current speed, leading to egg release. 
A second 'single trigger' hypothesis explains the induction of female spawning solely by a threshold concentration of sperm or associated chemical(s). This corresponds closely with the hypothesis proposed by Fujiwara et al. (1998) that the 'presence of gametes in the water column may act as a secondary cue for female spawning'. Young (1945) used laboratory studies to demonstrate that the presence of conspecific gametes in the water column was an important cue to spawning in the California mussel Mytilus californianus. Van Dover (1994) suggested a similar possibility for the siboglinid worm Riftia pachyptila. For example, the neurotransmitter serotonin $(5-\mathrm{HT})$ has been shown to stimulate the release and reinitiation of meiosis in oocytes of many marine bivalves including Argopecten purpuratus, Dreissena polymorpha, Patinopecten yessoensis, Spisula solidissima and $S$. sachalinensis (Matsunami \& Nomura 1982, Hirai et al. 1988, Ram et al. 1996, Martínez et al. 2005). Serotonin is generally contained in animal tissues. During sperm release under low current speeds, the concentration of sperm over clam aggregations is higher than during high current speeds. Our observations support the notion that female Calyptogena soyoae/okutanii can easily detect high concentrations of chemical cues under low current speeds. Importantly, induction of female spawning may not occur unless sperm concentrations (and any key chemical cues) exceed a threshold. According to this hypothesis, we suggest the following spawning scenario. First, water temperature increases, which induces spawning by males. Second, females detect the sperm/chemical concentration and are induced to spawn if a threshold concentration is reached. An experimental approach manipulating key cues (current speed and sperm concentration) is required to test these hypotheses. However, this hypothesis is consistent with the observed lower frequency of female versus male spawning. Presumably, sperm concentrations were lower than required to stimulate egg spawning during many events, due to low sperm release rates by males or high current speeds (leading to dilution of sperm concentrations) or both.

In addition to deep-sea observatories, the operators of submersibles and remotely operated vehicles are excellent resources for direct observations of the behavior and distribution of deep-sea animals. Spawning of at least 4 species of vent or seep species have been observed in situ using submersibles, including the siboglinid worm Riftia pachyptila in the East Pacific Rise (Van Dover 1994), the brachyuran crab Bythograea sp. in the Southern East Pacific Rise (Van Dover 2000) and 2 siboglinid worms Lamellibrachia sp. and Escarpia sp. both on the Louisiana slope (Tyler \& Young 1999). In all cases, however, the time scales of these observations were short (1 to $2 \mathrm{~h}$ ). Our knowl- edge of the reproductive biology of vent and seep animals remains fragmentary. One key difficulty in studying reproductive biology is the need to examine temporal processes on scales of months to years. In this study, observations using a permanent deep-sea observatory have proven valuable in assessing the reproductive strategy of deep-sea animals. In the near future, we hope to develop simple and low-cost observatories to advance studies of deep-sea biology.

Acknowledgements. We thank H. Momma and K. Mitsuzawa of JAMSTEC, without whose efforts in developing and maintaining the long-term observatory this study would not have been possible. We are grateful to N. Iwasaki of Kochi University, and to K. Asahina and A. Nakajima of Nihon University for their help. Finally, we also thank the editor, P. Tyler, and an anonymous reviewer who provided valuable comments on the manuscript.

\section{LITERATURE CITED}

Barnes RD (1969) Invertebrate zoology. WB Saunders, Philadelphia, PA

Berg CJ (1985) Reproductive strategies of mollusks from abyssal hydrothermal vent communities. Bull Biol Soc Wash 6:185-197

Colaço A, Martins I, Laranjo W, Pires L and 7 others (2006) Annual spawning of the hydrothermal vent mussel, Bathymodiolus azoricus, under controlled aquarium conditions at atmospheric pressure. J Exp Mar Biol Ecol 333:166-171

Endow K, Ohta S (1990) Occurrence of bacteria in the primary oocytes of vesicomyid clam Calyptogena soyoae. Mar Ecol Prog Ser 64:309-311

Fiala-Médioni A, Le Pennec M (1989) Adaptive features of the bivalve molluscs associated with fluid venting in the subduction zone off Japan. Palaeogeogr Palaeoclimatol Palaeoecol 71:161-167

Fujikura K, Hashimoto J, Okutani T (2002) Estimated population densities of megafauna in two chemosynthesis-based communities: a cold seep in Sagami Bay and a hydrothermal vent in the Okinawa Trough. Benthos Res 57:21-30

Fujiwara Y, Tsukahara J, Hashimoto J, Fujikura K (1998) In situ spawning of a deep-sea vesicomyid clam: evidence for an environmental cue. Deep-Sea Res I 45:1881-1889

Gage JD, Tyler PA (1991) Deep-sea biology: a natural history of organisms at the deep-sea floor. Cambridge University Press, New York

Giese AC, Kanatani H (1987) Maturation and spawning. In: Giese AC, Pearse JS, Pearse VB (eds) Reproduction of marine invertebrates, Vol 9. Blackwell Scientific Publications and Boxwood Press, Palo Alto, CA

Hashimoto J, Ohta S, Tanaka T, Hotta H, Matsuzawa S, Sakai H (1989) Deep-sea communities dominated by the giant clam, Calyptogena soyoae, along the slope foot of Hatsushima Island, Sagami Bay, central Japan. Palaeogeogr Palaeoclimatol Palaeoecol 71:179-192

Hirai S, Kishimoto T, Kadam AL, Kanatani H, Koide SS (1988) Induction of spawning and oocyte maturation by 5-hydroxytryptamine in the surf clam. J Exp Zool 245: 318-321

Ito K (2004) Species composition of genus Calyptogena in Sagami Bay: a morphology-based study. Benthos Res 59: $61-66$ 
Kojima S, Ohta S (1997) Calyptogena okutanii n. sp. a sibling species of Calyptogena soyoae Okutani, 1957 (Bivalvia: Vesicomyidae). Venus 56:189-195

Kojima S, Fujikura K, Okutani T (2004) Multiple trans-Pacific migrations of deep-sea vent/seep-endemic bivalves in the family Vesicomyidae. Mol Phylogenet Evol 32:396-406

Lisin SE, Hannan KD, Kochevar RE, Harrold C, Barry JP (1997) Temporal variation in gametogenic cycle of vesicomyid clams. Invertebr Reprod Dev 31:307-318

Martínez G, Pérez MA, Mettifogo L, Wolff D (2005) Extracellular $\mathrm{Ca}^{2+}$ requirement for serotonin-induced release and meiosis reinitiation from prophase in oocytes of the scallop Argopecten purpuratus. Invertebr Reprod Dev 47:117-124

Matsunami T, Nomura T (1982) Induction of spawning by serotonin in the scallop Patinopecten yessoensis (Jay). Mar Biol Lett 3:353-358

Momma H, Mitsuzawa K, Kaiho Y, Hotta H (1994) Long term and real time observation on the deep sea floor off Hatsushima Island in Sagami Bay. JAMSTEC J Deep Sea Res 10:363-371 (in Japanese with English abstract)

Momma H, Mitsuzawa K, Kaiho Y, Iwase R, Fujiwara Y (1995) Long-term deep-sea floor observation off Hatsushima Island in Sagami Bay-one year in the Calyptogena soyoae clam colony. JAMSTEC J Deep Sea Res 11: 249-268 (in Japanese with English abstract)

Momma H, Iwase R, Mitsuzawa K, Kaiho Y, Fujiwara Y (1998) Preliminary results of a three-year continuous observation by a deep seafloor observatory in Sagami Bay, central Japan. Phys Earth Planet Inter 108:263-274

Naka J, Fujikura K, Hashimoto J (1991) New geological infornation of Calyptogena colony off Hatsushima, Sagami Bay. JAMSTEC J Deep Sea Res 7:1-5 (in Japanese with English abstract)

Okutani T, Egawa K (1985) The first underwater observation on living habit and thanatocoenosis of Calyptogena soyoae bathyal depth of Sagami Bay. Venus 44:285-288

Pechenik JA (2005) Biology of the invertebrates. McGrawHill, New York

Pennington JT (1985) The ecology of fertilization of echinoid eggs: the consequences of sperm dilution, adult aggrega-

Editorial responsibility: Steven Morgan (Contributing Editor), Bodega Bay, California, USA tion, and synchronous spawning. Biol Bull (Woods Hole) 169:417-430

Ram JL, Fong PP, Kyozuka K (1996) Serotonergic mechanisms mediating spawning and oocyte maturation in the zebra mussel, Dreissena polymorpha. Invertebr Reprod Dev 30: 29-37

Sakai H, Gamo T, Endo K, Ishibashi J and 6 others (1987) Calyptogena colonies on the seabed off Hatsushima, Sagami Bay, a geochemical study with Shinkai 2000. In: The 3rd Symposium on the deep-sea research using the submersible 'Shinkai 2000' system. Tech Rep JAMSTEC, JAMSTEC, Yokosuka City, p 75-90

Sheltema RS (1994) Adaptations for reproduction among deep-sea benthic molluscs: an appraisal of the existing evidence. In: Young CM, Eckelbarger KJ (eds) Reproduction, larval biology, and recruitment of the deep-sea benthos. Columbia University Press, New York

Tsunogai U, Ishibashi J, Wakita H, Gamo T, Masuzawa T, Nakatsuka T, Nojiri Y, Nakamura T (1996) Fresh water seepage and pore water recycling on the seafloor: Sagami Trough subduction zone, Japan. Earth Planet Sci Lett 138: 157-168

Tyler PA (1988) Seasonality in the deep sea. Oceanogr Mar Biol Annu Rev 26:227-258

Tyler PA, Young CM (1999) Reproduction and dispersal at vents and cold seeps. J Mar Biol Assoc UK 79: 193-208

Tyler PA, Young CM, Dolan E, Arellano SM, Brooke SD, Baker $M$ (2006) Gametogenic periodicity in the chemosynthetic cold-seep mussel 'Bathymodiolus' childressi. Mar Biol 150: 829-840

Van Dover CL (1994) In situ spawning of hydrothermal vent tubeworms (Riftia pachyptila). Biol Bull (Woods Hole) 186: 134-135

Van Dover CL (2000) The ecology of deep-sea hydrothermal vents. Princeton University Press, Princeton, NJ

Young CM (2003) Deep-sea ecosystems. In: Tyler PA (ed) Ecosystems of the World Book 28. Elsevier, Amsterdam

Young RT (1945) Stimulation of spawning in the mussel (Mytilus californianus). Ecology 26:58-69

Submitted: June 6, 2006; Accepted: August 21, 2006

Proofs received from author(s): February 27, 2006 